\title{
PELATIHAN MANAJEMEN KEUANGAN BAGI PELAKU UKM DI TENGAH PANDEMIK COVID-19
}

\author{
Baiq Reinelda Tri Yunarni'), Nurul Hidayati Indra Ningsih"1), Dedy Iswanto1) \\ 1)Prodi Ilmu Administrasi Bisnis, Fisipol, Universitas Muhammadiyah Mataram, Mataram, NTB, Indonesia \\ Corresponding author : Nurul Hidayati Indra Ningsih \\ E-mail : indraningsih21@gmail.com
}

Diterima 12 Oktober 2020, Direvisi 20 Oktober 2020, Disetujui 20 Oktober 2020

\begin{abstract}
ABSTRAK
Terbatasnya kemampuan kebanyakan pelaku UKM dalam mengatur keuangan usahanya, menyebabkan terbengkalainya keuangan usaha mereka, hal inilah kemudian menyebabkan banyak pelaku UKM yang gagal untuk bisa tetap eksis dan berkembang. Berdasarkan hasil wawancara dengan para peserta sebelum kegiatan program pengabdian kepada masyarakat (PPKM), mereka tidak pernah melakukan pencatatan keuangan usaha mereka. Mereka hanya mencatat jumlah hutang pelanggan saja, tidak mencatat jumlah uang masuk maupun uang keluar, dan mereka tidak memisahkan uang pribadi dengan uang usaha. Inilah yang menjadi pemicu kegagalan kebanyakan para pelaku UKM sering terlibat masalah modal usaha, karena modal usaha sering digunakan juga untuk keperluan pribadi. Pengabdian Kepada Masyarakat ini bertujuan untuk memberikan pengetahuan kepada para peserta pentingnya membuat laoran keuangan atau pencatatan keuangan usaha. Pelaksanaan kegiatan pengabdian kepada masyarakat sudah berjalan dengan baik dan lancar. Hasil dari pelaksanaan kegiatan tersebut semua tahapan pelaksanaan kegiatan berjalan sesuai dengan yang direncanakan.
\end{abstract}

Kata kunci: manajemen keuangan; usaha kecil dan menengah (UKM); covid-19.

\begin{abstract}
The limited ability of most SMEs to manage their business finances, has led to the neglect of their business finances, and this has led to many SMEs who have failed to continue to exist and develop. Based on the results of our interviews with the participants before the activities of the community service program (PPKM), they never did financial records of their friends. They only record the amount of customer debt, do not record the amount of money in and out, and they do not separate personal money from business money. This is what triggers the failure of most SMEs are often involved in business capital problems. Because venture capital is often used also for personal needs. Community Service aims to provide knowledge to the participants the importance of making financial reports or recording financial business. The implementation of community service activities has been going well and smoothly. The results of the implementation of these activities all stages of the implementation of activities run as planned.
\end{abstract}

Keywords: financial management; small and medium enterprises (SMES); covid-19.

\section{PENDAHULUAN}

Saat ini, sangat marak munculnya usaha kecil menengah di tengah-tengah masyarakat. Hal ini didukung dengan banyaknya informasiinformasi yang tersebar dan berkembang terkait dengan bagaimana memulai wirausaha untuk meningkat perekonomian pribadi khususnya dan prekonomian daerah pada umumnya. Untuk memulai berwirausaha juga tidak memerlukan banyak modal, tapi bagaimana keahlian, kreatifitas dan ide-ide yang dimiliki seseorang untuk merealisasikan usahanya.

Di Desa Sandik, terdapat banyak UKM dalam berbagai bidang, usahanya rata-rata memiliki prospek yang baik kedepannya. Namun ada saja kendala yang sering dikeluhkan yaitu para pelaku UKM mini mengatakan bahwa setiap harinya mereka selalu merasa mendapatkan keuntungan yang tinggi, namun ketika dihitung tidak sesuai dengan yang mereka perkirakan. Berdasarkan hal ini, kita lihat bahwa mereka tidak membuat pencatatan maupun laporan keuangan atas usaha yang dijalankan, maka hal inilah penyebabnya.

Pada umumnya rata-rata UKM banyak yang belum tahu bagaimana mengelola keuangan usahanya dengan keuangan pribadi 
atau rumah tangga. Begitu pula dengan pembukuan keuangan, UKM kebanyakan malas untuk membuat laporan keuangan usahanya karena mereka merasa ribet dan hanya terfokus pada produksi dan penjualan. Hal ini juga dikarenakan, masyarakat di Desa Sandik, banyak yang tidak lulus SMP bahkan SMA, tentunya ini mempengaruhi pengetahuan terkait dengan ilmu manajemen keuangan yang dimiliki oleh masyarakat pelaku UKM di Desa Sandik. Hal hal ini sesuai dengan teori yang dikemukakan oleh Andreas,2011, bahwa kelemahan usaha kecil adalah kekurangan dana untuk memenuhi beban mereka dalam beberapa bulan ke depan. Ditambah lagi dengan belum adanya pemisahan keuangan usaha dan keuangan rumah tangganya.

Seperti yang dikutip dalam artikel Manoppo dan Frendy (2018), dalam rangka untuk mengembangkan Usaha Kecil dan Menengah (UKM), salah satu faktor penting yang tidak boleh dilupakan para pengusaha adalah pembukuan. Pembukuan sederhana pada usaha kecil dan menengah cukup penting untuk kemajuan usaha sendiri. Salah satu penyebab UMKM sulit berkembang adalah sistem akuntansi yang buruk pada UKM tersebut. Hal ini disebabkan oleh, kurangnya perhatian pemerintah terhadap hal ini, serta masih banyak pelaku UKM yang enggan memikirkan hal rumit seperti masalah akuntansi dan manajemen keuangan. Mereka hanya berpikir cukup dengan mendapatkan keuntungan, maka bisnis atau UMKM yang mereka miliki bisa berjalan dan berkembang.

Ditambah lagi dengan kondisi saat ini, di seluruh dunia dan Indonesia sedang dilanda bencana, yaitu hadirnya virus Covid-19. Virus ini mengharuskan kita menjaga jarak (social distancing). Mulai bulan Maret 2020, di seluruh Indonesia dihimbau untuk Work From Home (WFH) atau bekerja dari rumah. Kondisi ini membuat perekonomian memburuk, sehingga menurunkan pendapatan masyarakat secara umum. Dengan keadaan ini akan menambah PR para pelaku UKM, yaitu bagaimana bisa tetap eksis usahanya, meskipun tengah dilanda pandemic covid-19.

Berdasarkan hasil observasi dan wawancara yang telah dilakukan oleh TIM PKM, permasalahan yang dihadapi UKM Desa Sandik adalah sebagai berikut :

1. Belum terealisasikan potensi yang dimiliki UKM, karena minimnya pengetahuan manajemen keuangan/permodalan.

2. Belum adanya kesadaran UKM untuk membenahi manajemen keuangan sehingga dapat menyelesaikan permasalahan keuangannya terutama berkaitan dengan masalah permodalan
3. Masyarakat, pelaku UKM tidak memiliki pengetahuan atau ilmu manajemen keuangan untuk bisa membuat laporan keuangan usahanya. Serta bagaimana memisahkan antara keuangan usaha dengan keuangan pribadi (rumah tangga).

Dengan adanya penyusunan laporan keuangan maka kegiatan-kegiatan yang dilakukan pun akan ada data-data atau laporannya secara detail, hal ini akan membuat kemudahan sebuah UMKM untuk beroperasi secara baik dan efisien, serta UMKM tersebut pun akan dapat menganalisis kekurangan serta kelebihan yang dimiliki agar dapat mengembangkan dan memajukan UMKM itu sendiri. (Sasongko dan Rina, 2019)..

\section{METODE}

Tim Pengabdian Kepada Masyarakat dari universitas Muhammadiyah Mataram akan melakukan kegiatan Program Pengabdian Kepada Masyarakat (PPKM), metode pelaksanaannya dibagi menjadi beberapa tahap, alur pelaksanaan dilakukan tiga tahap secara berurutan seperti yang ditunjukkan pada Gambar 1 berikut ini :

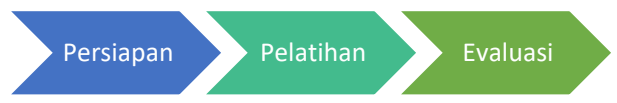

Gambar 1. Alur Tahap Pelaksanaan Kegiatan Pelatihan

1. Tahap Persiapan

Pada tahap persiapan ini Tim PKM menentukan lokasi kegiatan PKM. Dan ditentukanlah di Desa Sandik. Kemudian melalukukan survei, ke Dinas Koperasi, untuk mencari tahu jumlah Pelaku usaha kecil dan menengah di Desa Sandik. Karena banyak yang belum terdaftar, maka kami menentukan Peserta kegiatan ini adalah Pelaku UKM yang belum mendaftarkan Usaha mereka. selanjutya survei lokasi kegiatan yaitu di Aula kantor Desa dan melakukan koordinasi dengan kepala Desa, staff Desa untuk menentukan pelaksanaan kegiatan pelatihan.

2. Tahap Pelatihan

Pada tahap pelatihan yang dilakukan tim Program Pengabdian Kepada Masyarakat (PPKM) yaitu :

a. Memberikan materi tentang permasalahan yang sering di alami oleh para pelaku UKM pada umumnya hingga ke bagaimana solusi atau saran-saran agar para peserta bisa menghadapi 
permsaalahan seperti yang sudah kita ungkapkan.

b. Pelatihan menyusun laporan keuangan sederhana UKM, pencatatan Kas keluar dan Kas masuk

c. Sebelum kegiatan berakhir, kami melakukan diskusi Tanya jawab sehingga apa yang kami sampaikan dapat dipahami dan dimengerti dan bisa diaplikasikan. Sehingga apa yang kami sampaikan dan berikan dapat memberikan manfaat untuk peserta kegiatan PKM ini

3. Tahap Evaluasi

Evaluasi program PKM ini dilakukan secara berkala setelah kegiatan berakhir, dilakukan setiap 1 bulan sekali. Evaluasi yang dilakukan meliputi:

a. Keberlanjutan dalam kegiatan PPKM yaitu menjadikan para peserta sebagai mitra untuk dijadikan sebagai penelitian apakah dengan konsistennya para pelaku UKM menyusun laporan keuanga dapat membuat uaha mereka bisa tetap eksis dan berkembang.

b. Evalusi terhadap hasil kegiatan PPKM, apakah para peserta dapat membaca peluang yang ada sehingga usahanya laris dan bisa berkembang.

c. Evaluasi kreatifitas para peserta, apakah para peserta sudah bisa belajar untuk mencari informasi dan pengetahuan mengenai untuk usaha mereka, agar usaha yang mereka jalani ini bisa mengikuti perkembangan kemajuan saat ini. Misalnya mulai berjualan online (jika bisa) dan dengan system dilevery order (pengantaran) memanfaatkan tenaga keluarga jika ada yang menganggur atau kurir online.

\section{HASIL DAN PEMBAHASAN}

Dengan munculnya bencana virus Corona atau Covid-19 yang mendunia ini, menimbulkan krisis ekonomi secara menyeluruh. Karena virus ini memaksa masyarakat untuk menjaga diri dengan diam dirumah dan melakukan karantina secara mandiri untuk memutus rantai penyebaran covid-19. Selama masa karantina, membuat banyak sector mati suri misalnya sektor pariwisata, dan sektor pendidikan, hal ini menyebabkan menurunya pendapatan sebagian besar masyarakat. Banyak yang kesulitan perekonomian karena matinya mata pencaharian mereka.

Oleh karena itu kami memiliki gagasan untuk memberikan pelatihan kepada para pelaku UKM agar dapat bisa tetap eksis ditengah pandemik covid-19 ini. Jika mereka mengabaikan pencatatan laporan keuangan, ini dapat menurunkan kinerja keuangan usaha mereka. Karena tidak di cacatat dengan baik

Sebelum kegiatan pengabdian dilakukan, terlebih dahulu diadakan koordinasi dengan mitra yaitu desa Sandik untuk merencanakan waktu dan tempat kegiatan pengabdian masyarakat di desa tersebut. Setelah waktu dan tempat disepakati, melakukan searching (pencarian) data peserta yang akan diundang. Setelah itu melakukan pendataan siapa saja yang akan diundang untuk mengikuti kegiatan. Dan tidak lupa mengingatkan untuk menggunakan masker.

Kegiatan ini berlangsung pada hari Sabtu, tanggal 13 Juni 2020 bertempat di Aula Kantor desa Sandik. Tempat duduk untuk peserta ditata agar berjarak, sesuai protokol kesehatan memutus rantai penyebaran Covid-19. Semua peserta undangan hadir, tidak lupa menggunakan masker, Kepala desa Sandik juga ikut mengadiri acara. Kegiatan ini dibuka oleh kepala Desa Sandik pak H. Abdur Rahman, beliau juga memberikan sambutan, dan berterimakasih telah menyelenggarakan acara ini untuk memberikan ilmu kepada masyarakatnya.

Pelaksanaan kegiatan PKM ini dilakukan oleh dua (2) tim pengabdi dengan 2 pokok bahasan mengenai permasalahan UKM dan Pelatihan menyusun laporan keuangan. Waktu untuk kegiatan ini sangat terbatas, sehingga kami menyampaikan Poin-poin penting yang perlu diketahui peserta, untuk dapat dengan mudah dipahami. Ada juga peserta yang tidak mengikuti pelatihan ini sampai selesai karena ada kesibukan.

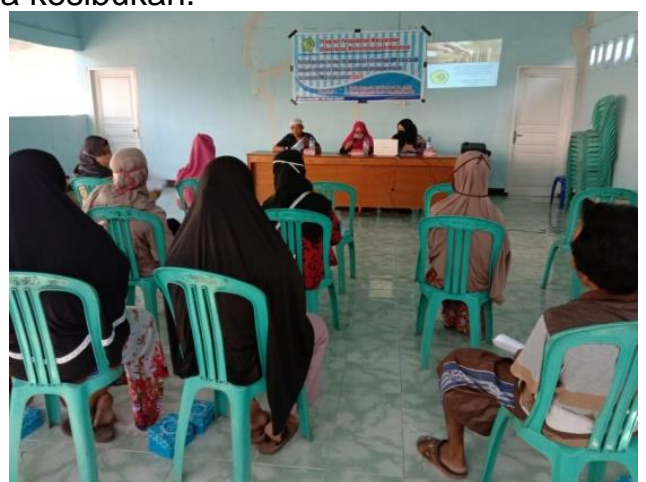

Gambar 2. Penyampaian materi oleh tim PKM

Materi pertama yang diberikan adalah mengenai permasalahan yang sering di alami oleh para pelaku UKM pada umumnya hingga ke bagaimana solusi atau saran-saran agar para peserta bisa menghadapi permasalahan seperti yang sudah diungkapkan. Selanjutkan memaparkan pentingnya menyusun laporan keuangan. 
Materi kedua yaitu Pelatihan menyusun laporan keuangan sederhana UKM, pencatatan Kas keluar dan Kas masuk, namun sebelumnya disampaikan pentingnya menyusun laporan keuangan ini kepada mereka. Dan mereka juga menyatakan bahwa mereka tidak paham cara menyusun laporan keuangan. Saat pemaparan cara penyusunan laporan keuangan, mereka antusias menyimak dengan seksama materi yang diberikan. Karena selama ini para peserta merasa tidak perlu melakukan pencatatan laporan keuangan karena mereka merasa tidak begitu penting dan sangat merepotkan. Sehingga setelah mendapatkan penjelasan tentang pentingnya penyusunan laporan keuangan, mereka tersadar akan pentingnya memahami dan melakukan pencatatan dan penyusunan laporan keuangan untuk usaha mereka.

Diakhir kegiatan dilakukan diskusi, metode Tanya-jawab, dari hasil diskusi ini dtemukan bahwa pengusaha UKM di Desa Sandik mengalami kendala di bidang permodalan, pengadaan alat dan pemasaran, sehingga untuk kegiatan dimasa yang akan datang tim pelaksana pengabdian kepada masyarakat harus lebih fokus pada bidang-bidang tersebut.

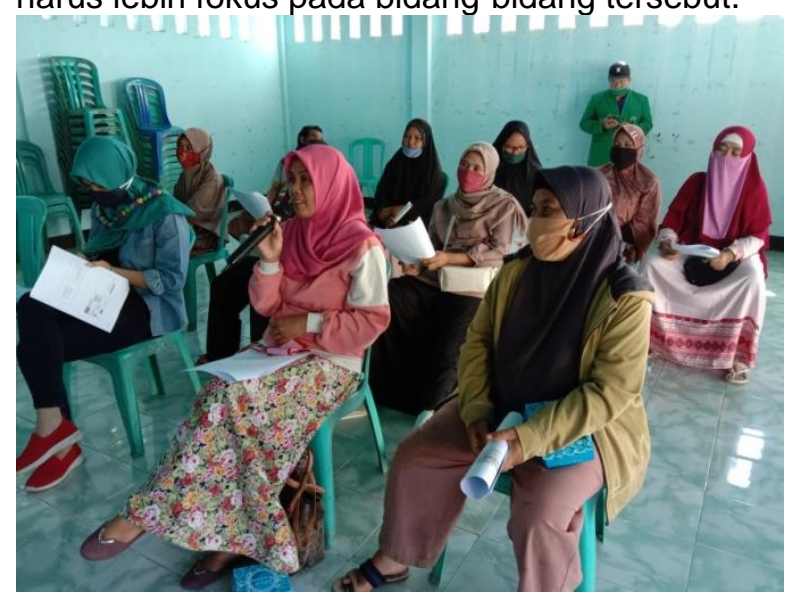

Gambar 3. Diskusi dan Tanya jawab dengan peserta

Saat diskusi, selain bertanya terkait bagaimana cara penyusunan laporan keuangan, banyak hal yang disampaikan oleh para peserta. Salah satunya adalah terkait dengan bagaimana mendapatkan modal tambahan dari pemerintah untuk UKM. Kami menjelaskan, berdasarkan amanat Undang-undang No. 20 Tahun 2008 terkait Usaha Mikro Kecial dan Menengah mengamanatkan pemberdayaan usaaha mikro, kecil dan menengaah dilaksanakan melalui sinergi pemerintah pusat, pemerintah daerah, dunia usaha dan masyarakat secara menyeluruh. Kementerian Koperasi dan UKM sebagai leading sector di dalam pemberdayaan UMKM tertuang di dalam
Rencana Strategis Kementerian Koperasi dan UKM, yaitu meningkatkan wirausaha baru dengan upaya penumbuhan 1 (satu) juta wirausaha pemula secara nasional. Untuk mencapai target tersebut, maka Kementerian Koperasi dan UKM berusaha mewujudkannya di dalam Program Bantuan Pemerintah dalam Upaya Pengembangan Wirausaha Pemula, nilai bantuan yang diberikan 10-13 juta per wirausaha pemula baik berupa dana tunai atau bantuan peralatan dan perlengkapan usaha sesuai bidangnya. Untuk mendapatkan bantuan tersebut peserta program harus melengkapi persyaratan yang telah di tetapkan. Untuk mendapatkan informasi lebih lanjut kami menyarankan para peserta untuk langsung ke Dinas Koperasi dan UKM untuk mendapatkan informasi yang lebih jelas terkait program tersebut.

Program pengabdian yang sudah dilaksanakan ini, diharapkan dapat menambah pengetahuan akan pentingnya manajemen keuangan yang diterapkan di UKM di sekitar Desa Sandik.

\section{SIMPULAN DAN SARAN Simpulan}

Melalui Pelatihan Manajemen

Keuangan khususnya pembukuan laporan keuangan sederhana ini diharapkan para peserta (pelaku UKM) di Desa Sandik Kecamatan Batu Layar Kabupaten Lombok Barat mengetahui lebih banyak tetang Manajemen Keuangan praktis sehingga lebih siap dalam menghadapi persaingan yang semakin ketat dan bisa meningkatkan pendapatan

Melalui pelatihan Manajemen Keuangan, peserta (pelaku UKM) lebih paham dan memiliki laporan keuangan yang akurat yang sangat berguna untuk mengetahui keberhailan usaha yang dilakukan dan menjadikan usahanya diekspansi ke daerahdaerah lain.

Melalui pelatihan ini para peserta diharapkan dapat tetap bertahan dalam kondisi ekonomi yg tidak stabil, termasuk pada saat pandemic COVID-19 saat ini.

\section{Saran}

Mengingat peserta yang mendapat kesempatan mengikuti pelatihan ini terbatas karena kondisi pandemik sekarang ini, maka perlu adanya upaya untuk melanjutkan kegiatan pelatihan serta perlu adanya pembimbing secara berkelanjutan untuk mendapatkan hasil yang optimal. Disamping itu untuk kegiatan selanjutnya diperlukan dana yang lebih besar. Selain itu, waktu yang sangat terbatas karena kesibukan para peserta, diharapkan yang ingin 
melakukan pelatihan pencatatan dan penyusunan laporan keuangan dilakukan lebih dari 1 hari. Agar lebih banyak waktu untuk dapat menjelaskan hal tersebut, sehingga peserta dapat memahami dengan maksimal

\section{UCAPAN TERIMA KASIH}

$\begin{array}{llr}\text { Kami } & \text { selaku tim } & \text { pengabdian } \\ \text { mengucapkan terimakasih ke } & \text { Lembaga } \\ \text { Pengabdian Pada Masyarakat } & \text { (LPPM) }\end{array}$ Universitas Muhammadiyah Mataram yang telah mendanai kegiatan pengabdian ini melalui hibah pengabdian Universitas Muhammadiyah Mataram. Sehingga kegiatan kami terlaksana dengan baik. Kami juga mengucapkan terimakasih Kepada Bapak Kepala Desa Sandik Kecamatan Batulayar dan perangkatnya yang telah memfasilitasi kegiatan ini. sehingga kegiatan pengabdian ini dapat terlaksana dengan baik.

\section{DAFTAR RUJUKAN}

Andreas. (2011). Manajemen Keuangan UKM. Yogyakarta: Graha IImu.

https://www.jurnal.id/id/blog/contoh-laporankeuangan-khusus-ukm-yang-sesuaidengan-sak-emkm/

Leny Sulistyowati.. (2013). Panduan Praktis Memahami Laporan Keuangan. Jakarta Pusat: Elex Media Komputindo.

Manoppo, Wilfried Seth dan Frendy A. O. Pelleng. (2018). Pelatihan Penyusunan Laporan Keuangan Dengan Teknik Pembukuan Sederhana Bagi Pelaku Usaha UMKM Di Kecamatan Malalayang Kota Manado Provinsi Sulawesi Utara https://media.neliti.com/media/publicatio ns/269354-pelatihan-penyusunanlaporan-keuangan-de-158debd4.pdf

Putra dan Elisabeth. (2012). Penyusunan Laporan Keuangan untuk usaha kecil dan menengah diakses dari https://repository.uksw.edu/bitstream/12 3456789/1281/5/PROS_Hermon\%20AP

Elisabeth\%20PK_Penyusunan\%20Lapo ran\%20Keuangañ\%20untuk\%20Usaha_ Fulltext.pdf

Sasongko, Noer dan Rina Trisnawati. TATA KELOLA KEUANGAN YANG BAIK BAGI UMKM. Seminar Nasional \& Call For Paper Seminar Bisnis Magister Manajemen (SAMBIS-2019) ISSN: 26851474 "Membangun Ekonomi Kreatif yang Berdaya Saing". https://publikasiilmiah.ums.ac.id/bitstrea $\mathrm{m} /$ handle/11617/11093/22.\%20Noer\%2 C\%20Rina\%2C\%20Erma\%20dan\%20E vi_.pdf?sequence $=1$ \&isAllowed $=y$ 